\title{
Małgorzata Puto
}

Uniwersytet Mikołaja Kopernika, Toruń

\section{Dyskryminacja \\ pod względem językowym \\ w systemie jednolitej ochrony patentowej}

DOI: http://dx.doi.org/10.12775/SIT.2015.011

\section{Patent europejski o jednolitym skutku - charakterystyka}

Patent jest przedmiotem prawa własności intelektualnej oraz ograniczonym w czasie prawem do wynalazku, który jest nowy, posiada poziom wynalazczy i nadaje się do przemysłowego stosowania ${ }^{1}$. Przez uzyskanie patentu nabywa się prawo wyłącznego korzystania $z$ wynalazku w sposób zarobkowy lub zawodowy ${ }^{2}$. W doktrynie podnosi się, że prawo wyłącznego korzystania $z$ wynalazku to pozytywnie określona sfera możności korzystania $z$ niego, polegająca na możliwości stosowania wynalazku oraz czerpania korzyści z „posiadania" i dysponowania nim³ .

${ }^{1}$ Art. 24 ustawy z dnia 30 czerwca 2000 r. Prawo własności przemysłowej (Dz.U. $2001 \mathrm{Nr} 49$, poz. 508, ze zm.).

2 Art. 63 ust. 1 ustawy z dnia 30 czerwca 2000 r. Prawo własności przemysłowej (Dz.U. $2001 \mathrm{Nr} 49$, poz. 508, ze zm.).

${ }^{3}$ M. du Vall, Prawo patentowe, Warszawa 2008, s. 228; A. Szajkowski, Patent tymczasowy. Patent. Świadectwo autorskie, w: Komentarz do prawa wynalazczego, red. S. Sołtysiński, A. Szajkowski, T. Szymanek, Warszawa 1990, s. 92. 
Patent europejski o jednolitym skutku składa się na system ochrony własności przemysłowej w ramach Unii Europejskiej. Zgodnie $z$ rozporządzeniem Parlamentu Europejskiego i Rady Unii Europejskiej nr 1257/2012 z dnia 17 grudnia 2012 r. wprowadzającego wzmocnioną współpracę w dziedzinie tworzenia jednolitego systemu ochrony patentowej ${ }^{4}$, patent europejski ma jednolity skutek w państwach członkowskich uczestniczących we wzmocnionej współpracy w dziedzinie tworzenia jednolitego systemu ochrony patentowej, na mocy decyzji Rady 2011/167/UE ${ }^{5}$ (dalej: decyzja Rady) lub na mocy decyzji przyjętej zgodnie $z$ art. 331 Traktatu o funkcjonowaniu Unii Europejskiej ${ }^{6}$.

Jednolity patent europejski obowiązywać będzie automatycznie we wszystkich krajach członkowskich uczestniczących we wzmocnionej współpracy (poza którą znajdują się jedynie Chorwacja ${ }^{7}$, Hiszpania i Włochy) po udzieleniu przez Europejski Urząd Patentowy (dalej: EPO). Obowiązywać ma bez wymaganej dotychczas walidacji, w tym bez tłumaczenia na język krajowy. Występował będzie w jednej z trzech możliwych wersji językowych: angielskiej albo niemieckiej, albo francuskiej.

\section{Jednolity sąd patentowy}

Ustanowienie jednolitej ochrony patentowej jest ściśle powiązane z utworzeniem Jednolitego Sądu Patentowego (dalej: JSP). Stanowi on trzeci element „pakietu patentowego”. Pozostałymi dwoma są: rozporządzenie Parlamentu Europejskiego i Rady nr 1257/2012 z 17 grudnia 2012 r. wprowadzające wzmocnioną współpracę $\mathrm{w}$ dziedzinie tworzenia jednolitego systemu ochrony patentowej oraz rozporządzenie Rady nr 1260/2012 z 17 grudnia 2012 r.

${ }^{4}$ Dz.Urz. UE L 361 z 31 grudnia 2012 r., s. 1.

${ }^{5}$ Decyzja Rady Unii Europejskiej z dnia 10 marca 2011 r. w sprawie upoważnienia do podjęcia wzmocnionej współpracy w dziedzinie tworzenia jednolitego systemu ochrony patentowej (2011/167/UE).

${ }^{6}$ Wersja skonsolidowana: Dz.Urz. UE C 83 z dnia 30 marca 2010 r., s. 146.

7 Republika Chorwacji przystąpiła do Unii Europejskiej 1 lipca 2013 r. 
wprowadzające wzmocnioną współpracę w dziedzinie tworzenia jednolitego systemu ochrony patentowej w odniesieniu do odpowiednich ustaleń dotyczących tłumaczeñ ${ }^{8}$.

Dwadzieścia cztery państwa członkowskie Unii Europejskiej 19 lutego 2013 roku podpisały międzynarodowe porozumienie w sprawie JSP. Do podpisania umowy doszło przy okazji odbywającej się w Brukseli Rady Unii Europejskiej ds. Konkurencyjności. Republika Włoska, mimo że nie uczestniczy we wzmocnionej współpracy, postanowiła podpisać porozumienie. Obecnie Chorwacja, Hiszpania oraz Polska, która tym razem nie zdecydowała się przystąpić do porozumienia, są jedynymi państwami członkowskimi UE, które pozostają poza obszarem umowy o jednolitym sądzie patentowym. Jednakże pozostaje ona wciąż otwarta do podpisu. Jej obowiązywanie jest uwarunkowane ratyfikowaniem przez co najmniej 13 państw członkowskich, w tym przez Francję, Niemcy i Wielką Brytanię, i wejdzie w życie jedynie na terytorium tych państw, które ją ratyfikowały.

Jednolity Sąd Patentowy to sąd międzynarodowy z główną siedzibą poza Polską. W zakres jego kognicji będą wchodzić sprawy dotyczące patentów europejskich o jednolitym skutku, jak również patentów europejskich udzielanych na mocy konwencji z 5 października 1973 roku$^{9}$. oraz dodatkowych praw ochronnych. Składać będzie się $\mathrm{z}$ oddziału centralnego $\mathrm{w}$ Paryżu $\mathrm{z}$ filiami w Londynie i Monachium oraz oddziałów lokalnych i regionalnych. Państwa będą mogły wnioskować o utworzenie oddziałów lokalnych na ich terytorium. Oddział regionalny będzie mógł zostać utworzony dla dwóch lub więcej wnioskujących państw ${ }^{10}$.

${ }^{8}$ Dz.Urz. UE L 361 z 31 grudnia 2012 r., s. 89.

${ }^{9}$ Konwencja o udzielaniu patentów europejskich, sporządzona w Monachium 5 października 1973 r. (Dz.U. z 2004 r. Nr 79, poz. 737).

${ }^{10}$ Art. 7 Porozumienia w sprawie Jednolitego Sądu Patentowego (2013/C 175/01). 


\section{Pojęcie dyskryminacji i uregulowania prawne}

Dyskryminacja (łac. discrimino - „rozróżniam”) oznacza odmienne traktowanie różnych podmiotów, które znajdują się w podobnej sytuacji. Są to działania, których celem jest pozbawienie dyskryminowanych osób praw i korzyści przysługujących każdemu człowiekowi ${ }^{11}$. W rozumieniu słownikowym za dyskryminację przyjmuje się również każde działanie odmawiające określonym osobom (lub grupom osób) takiego samego traktowania jak innych $\mathrm{z}$ powodu ich przynależności do określonej grupy społecznej, religijnej, narodowej itp. ${ }^{12}$

Po II wojnie światowej powstał cały szereg dokumentów w zakresie zwalczania dyskryminacji, m.in.: Powszechna deklaracja praw człowieka ONZ (1948), Międzynarodowa konwencja w sprawie likwidacji wszelkich form dyskryminacji rasowej (1966), Europejska konwencja praw człowieka i podstawowych wolności, Rada Europy (1950), Międzynarodowy pakiet praw obywatelskich i podstawowych wolności (1966).

Zasada równości jest jedną z fundamentalnych zasad prawa Unii Europejskiej. Również art. 21 Karty praw podstawowych zakazuje wszelkiej dyskryminacji, w szczególności ze względu na płeć, rasę, kolor skóry, pochodzenie etniczne lub społeczne, cechy genetyczne, język, religię lub przekonania, poglądy polityczne lub wszelkie inne poglądy, przynależność do mniejszości narodowej, majątek, urodzenie, niepełnosprawność, wiek lub orientację seksualną. W zakresie zastosowania traktatów i bez uszczerbku dla ich postanowień szczególnych zakazana jest wszelka dyskryminacja ze względu na przynależność państwową.

Powszechna deklaracja praw człowieka z 1948 roku głosi, iż każda osoba jest uprawniona do korzystania ze wszystkich praw

11 J. Siuta, Stownik psychologii, Kraków 2005, s. 68.

12 W. Kopaliński, Słownik wyrazów obcych i zwrotów obcojęzycznych, Warszawa 1988, s. 133. W wydaniu słownika z 2005 r.: „dyskryminacja to prześladowanie poszczególnych osób i grup społecznych albo ograniczanie ich praw ze względu na rasę, narodowość, wyznanie, płeć itp.” 
i wolności ogłoszonych w niniejszej deklaracji bez jakiejkolwiek różnicy, zwłaszcza ze względu na rasę, kolor skóry, płeć, język, religię, poglądy polityczne lub jakiekolwiek inne, pochodzenie narodowe lub społeczne, majątek, urodzenie lub jakąkolwiek inną sytuację.

Zgodnie $z$ art. 1 protokołu 2 do Konwencji o ochronie praw człowieka i podstawowych wolności, korzystanie $z$ każdego prawa powinno być zapewnione bez dyskryminacji wynikającej $z$ takich powodów jak płeć, rasa, kolor skóry, język, religia, przekonania polityczne lub inne, pochodzenie narodowe lub społeczne, przynależność do mniejszości narodowej, majątek, urodzenie lub z jakichkolwiek innych przyczyn. Nikt nie może być dyskryminowany przez jakiekolwiek władze publiczne $z$ któregokolwiek $z$ wymienionych powodów.

Europejska konwencja praw człowieka z 1950 roku zabrania wszelkiej dyskryminacji osób ze względu na ich płeć, rasę, kolor skóry, wyznanie, poglądy polityczne lub inne, pochodzenie narodowe i społeczne, przynależność do mniejszości narodowych, majątek, urodzenie czy $\mathrm{z}$ innych powodów ${ }^{13}$.

\section{Dyskryminacja w zakresie systemu jednolitej ochrony patentowej}

System jednolitej ochrony patentowej jest od ponad dwóch lat tematem debat publicznych i licznych protestów zarówno ze strony podmiotów gospodarczych, jak i ekspertów $z$ dziedziny prawa patentowego. Podnoszone są przede wszystkim kwestie dyskryminacji ze względu na język przedsiębiorców z państw innych niż Anglia, Francja i Niemcy, a także nierówność gospodarczą państw członkowskich, która może ulec pogłębieniu po wprowadzeniu systemu jednolitej ochrony patentowej ${ }^{14}$.

${ }^{13}$ Art. 14 Konwencji o ochronie praw człowieka i podstawowych wolności, Rzym, 4 listopada 1950, zmieniona Protokołem nr 11 i 14 (Dz.U. z 1993 r. Nr 61, poz. 284).

${ }_{14}$ Zob. np. list otwarty S. Sołtysińskiego, A. Szajkowskiego, J. Szwaji, R. Markiewicza, A. Nowickiej i R. Skubisza, opublikowany w maju 2012 r. 


\subsection{Język}

Od przełomu 2004 i 2005 roku uwidacznia się tendencja do redukowania liczby języków w instytucjach europejskich, $\mathrm{z}$ preferencją języków: angielskiego, francuskiego i niemieckiego. Uwzględniona została ona również przy tworzeniu systemu jednolitej ochrony patentowej. Jednolite patenty będą przez EPO w Monachium udzielane i publikowane $\mathrm{w}$ jednym $\mathrm{z}$ trzech języków używanych przez ten urząd (angielskim, francuskim lub niemieckim), a zgłaszający patent nie będą mieli obowiązku dostarczenia tłumaczeń do krajowych urzędów patentowych. Taki obowiązek jest obecnie nałożony przez art. 6 ust. 2 ustawy z dnia 14 marca 2003 r. o dokonywaniu europejskich zgłoszeń patentowych oraz skutkach patentu europejskiego w Rzeczypospolitej Polskiej, w stosunku do zgłaszającego patent europejski przyjęty w konwencji monachijskiej z 1973 roku, którego zgłoszenie wyznacza Polskę jako kraj ochronny. Taka zmiana zdecydowanie pogorszy sytuację w szczególności małych i średnich przedsiębiorców (dalej: mśp) prowadzących działalność gospodarczą na terenie Polski. W konsekwencji przedsiębiorcy będą zmuszeni zatrudnić tłumaczy celem upewnienia się, że ich działalność nie naruszy czyichś uprawnień patentowych. Takie ograniczenie wolności gospodarczej stoi w sprzeczności z celami Unii.

Przedstawienie tłumaczenia będzie obowiązkowe dopiero po wystąpieniu sporu co do patentu ${ }^{15}$, jednak $z$ możliwością odstąpienia od tego wymogu ${ }^{16}$. Wprawdzie EPO wprowadził system tłumaczeń maszynowych, który umożliwia dokonanie tłumaczenia na dany język urzędowy Unii, ale mają one charakter jedynie informacyjny,

m.in. na stronach Polskiej Izby Rzeczników Patentowych, por. http://www. rzecznik patentowy.org.pl/nie_dla_pat_jed/List_otwarty.projekt.24.5.2012.pdf oraz w dodatku do „Rzeczpospolitej” z 18 czerwca 2012 r. (dostęp: 15 marca 2015 r.)

${ }^{15}$ Art. 49 ust. 5 projektu Porozumienia w sprawie Jednolitego Patentu (2013/C 175/01).

${ }^{16}$ Art. 50 ust. 1 projektu Porozumienia w sprawie Jednolitego Patentu (2013/C 175/01). 
pozbawiony mocy prawnej ${ }^{17}$. Natomiast dla patentów europejskich walidowanych w Polsce wiążący zakres wyznacza przede wszystkim treść tłumaczenia patentu opublikowana przez Urząd Patentowy ${ }^{18}$. Ponadto jeżeli zakres tłumaczenia jest węższy od wersji pierwotnej, przyjmuje się za autentyczną wersję przetłumaczoną. Nie sposób nie zauważyć, że w tym porównaniu jednolity patent wydaje się mniej korzystny dla polskich przedsiębiorców od patentu europejskiego. Również eksperci w dziedzinie prawa patentowego wypowiadają się dosyć sceptycznie odnośnie do planu wdrożenia jednolitej ochrony. „Nowe rozwiązania nie zapewniają właściwej równowagi między interesami silnych użytkowników systemu patentowego a interesem publicznym państw takich jak Polska, mających słabszy potencjał rozwoju innowacyjności i mniejsze środki - publiczne i prywatne - na badania i rozwój”" ${ }^{19}$.

Sytuacja, w której postępowanie ma toczyć się w jednym $z$ tylko trzech języków spośród wszystkich obowiązujących w 25 państwach, które przystąpiły do systemu, stanowi pogwałcenie prawa do równości oraz wolności od dyskryminacji. Obywatele pozostałych państw, mogący nie posługiwać się żadnym $z$ trzech urzędowych języków EPO, będą mieć utrudniony dostęp do treści obowiązujących patentów. Kwestia ta byłaby znacznie mniej kontrowersyjna, gdyby językiem urzędowym EPO został wyłącznie język angielski, stanowiący główny język biznesu i handlu międzynarodowego ${ }^{20}$. Taką propozycję wystosowało Królestwo Hiszpanii podczas prowadzonych negocjacji odnośnie do wprowadzenia jednolitej ochrony

17 Usługa tłumaczenia maszynowego Patent Translate jest dostępna na stronie internetowej: http://www.epo.org/searching/free/patent-translate. html (dostęp: 29 marca 2015 r.).

18 Art. 7 ust. 2 ustawy o dokonywaniu europejskich zgłoszeń patentowych oraz skutkach patentu europejskiego w Rzeczypospolitej Polskiej z dnia 14 marca 2003 r (Dz.U. Nr 65, poz. 598, ze zm).

${ }^{19}$ Wypowiedź dr hab. A. Nowickiej, prof. Uniwersytetu Adama Mickiewicza w Poznaniu - prawnika, specjalistki od prawa własności intelektualnej, http:// www.for.org.pl/pl/debaty (dostęp: 31 sierpnia 2014 r.).

${ }^{20}$ Zob. H. Ullrich, Patent Protection in Europe: Integrating Europe into the Community or the Community into Europe?, European University Institute, Florence department of law, EUI Working Paper LAW No. 2002/5, s. 54. 
patentowej, co spotkało się ze zdecydowanym sprzeciwem ze strony Niemiec i Francji. Kwestia, dlaczego akurat te języki mają być językami urzędowymi EPO, jest nie do końca uzasadniona. O ile język niemiecki ma swoje uzasadnienie w liczbie sporów patentowych mających miejsce na terenie Niemiec oraz w statystykach, zgodnie z którymi zaraz po angielskim jest najczęściej wybieranym językiem obcym, to język francuski jako język urzędowy jest nie do końca logicznym rozwiązaniem. Ostatnie badania wykazują, że popularność języka francuskiego spada, a jego znajomość jest raczej niska wśród Europejczyków ${ }^{21}$. Statystyki pokazują, że hiszpański jest językiem ojczystym u 414 milionów ludzi, co daje Hiszpanii pierwsze miejsce wśród języków europejskich w skali świata. Zaraz za nią znajduje się język angielski (335 milionów). Języki niemiecki i francuski plasują się dopiero na piątym i siódmym miejscu odpowiednio 78 i 75 milionów osób posługuje się tymi językami jako ojczystymi ${ }^{22}$. Liczby te nieznacznie różnią się w statystykach Encyklopedii Encarta. Według tych danych angielski jest językiem, którym posługuje się 341 milionów ludzi na świecie, językiem hiszpańskim 322200 000, językiem niemieckim 100130 000, a francuskim 78 milionów ${ }^{23}$. W obliczu tych danych zrozumiały jest sprzeciw Hiszpanii odnośnie do uprzywilejowanej pozycji Francji i Niemiec w stosunku do pozostałych państw członkowskich w zakresie systemu tłumaczeń.

Zgodnie $z$ art. 20 Porozumienia w sprawie Jednolitego Sądu Patentowego, Sąd stosuje prawo Unii w całości i uznaje jego pierwszeństwo. Już w pierwotnych źródłach prawa Unii Europejskiej, jak art. 3 ust. 3 Traktatu o Unii Europejskiej ${ }^{24}$, zwalczanie dyskryminacji zostało wymienione jako jeden z celów Unii. Artykuł 18 Traktatu o funkcjonowaniu Unii Europejskiej ${ }^{25}$ wyraźnie zakazuje

${ }^{21}$ http://uk.reuters.com/article/2014/08/26/uk-france-economylanguage-idUKKBNOGQ1QE20140826 (dostęp: 31 sierpnia 2014 r.).

${ }^{22}$ http://www.ethnologue.com/statistics/size (dostęp: 31 sierpnia 2014 r.).

${ }^{23}$ http://web.archive.org/web/20070527180025/http://encarta.msn. com/media_701500404/Languages_Spoken_by_More_Than_10_Million_People.html (dostęp: 31 sierpnia 2014 r.).

${ }^{24}$ Wersja skonsolidowana: Dz.Urz. UE C 83 z 30.03.2010 r., s. 3.

${ }^{25}$ Wersja skonsolidowana: Dz.Urz. UE C 83 z 30.03.2010 r., s. 8. 
wszelkiej dyskryminacji ze względu na przynależność państwową. Protokół 2 do Konwencji o ochronie praw człowieka i podstawowych wolności, stanowiącej główną zasadę prawa Unii Europejskiej, wskazuje, że korzystanie $z$ każdego ustanowionego prawa winno być wolne od dyskryminacji ze względu na język. Należy zaznaczyć, że sprzyjanie realizacji celów Unii jest jednym z celów wzmocnionej współpracy.

W wyroku ze spraw połączonych C-274/11 oraz C-295/11 z 16 kwietnia 2013 roku Trybunał Sprawiedliwości Unii Europejskiej oddalił skargi Republiki Włoskiej i Królestwa Hiszpanii, kwestionujące zasadność wykorzystania mechanizmu wzmocnionej współpracy dla obowiązywania na terenie Unii Europejskiej systemu patentu jednolitego ${ }^{26}$. W skardze na decyzję Rady Królestwo Hiszpanii i Republika Włoska zarzuciły zakłócenie konkurencji i dyskryminację niektórych przedsiębiorstw ze względu na fakt, że handel produktami innowacyjnymi będzie, zgodnie $z$ systemem językowym przewidzianym w motywie 7 zaskarżonej decyzji, ułatwiony dla przedsiębiorców posługujących się językiem niemieckim, angielskim lub francuskim. Przewidywana wzmocniona współpraca ograniczy dostęp do informacji o zasięgu poszczególnych patentów zarówno przedsiębiorcom, jak i naukowcom pochodzących z państw członkowskich, które nie uczestniczą w tej współpracy, lub z państw członkowskich, których językiem oficjalnym nie jest niemiecki, angielski lub francuski.

Natomiast w sprawie C-566/10 P z 27 listopada 2011 roku w kontekście poszanowania narodowości i przynależności językowej poszczególnych państw członkowskich Trybunał uznał za słuszne skargi Republiki Włoskiej o uchylenie wyroku Sądu Unii Europejskiej z 13 września 2010 roku w sprawach połączonych T-166/07 i T-285/07 Republika Włoska przeciwko Komisji Europejskiej, w którym to wyroku Sąd nie uznał za zasadne stwierdzenia nieważności ogłoszeń o konkursach otwartych ze względu na brak publikacji w Dzienniku Urzędowym Unii Europejskiej pełnej

${ }^{26}$ Zob. wyrok Trybunału Sprawiedliwości Unii Europejskiej (Wielka Izba) w sprawie Królestwo Hiszpanii przeciwko Radzie Unii Europejskiej z dnia 16 kwietnia 2013 r., LEX Delta nr 5174107. 
treści spornych ogłoszeń o konkursach w językach urzędowych innych niż języki niemiecki, angielski i francuski, a także arbitralne ograniczenie do trzech języków wyboru drugiego języka do celów uczestnictwa w spornych konkursach, wszelkich kontaktów z Europejskim Urzędem Doboru Kadr oraz przeprowadzania egzaminów. Trybunał stwierdził, że sporne ogłoszenia o konkursach powinny zostać opublikowane w pełnym brzmieniu we wszystkich językach urzędowych, a kandydaci, którzy nie mogli zapoznać się z publikacją pełnej treści ogłoszeń w swoim ojczystym języku, znajdowali się w sytuacji mniej korzystnej niż kandydaci, których język ojczysty był jednym $z$ trzech języków, w których opublikowano sporne ogłoszenia o konkursach w pełnym brzmieniu ${ }^{27}$.

Można zauważyć tutaj pewną rozbieżność w orzecznictwie Trybunału, gdyż brak dostępności obowiązujących patentów w językach ojczystych potencjalnych naruszycieli jest takim samym naruszeniem równości językowej jak w przytoczonym orzeczeniu.

Sytuacja, w której przedsiębiorcy, w żaden sposób niezobowiązani do znajomości języków urzędowych EPO, muszą zapoznać się z patentami w językach sobie obcych, by uchronić się przed zarzutem naruszenia cudzego patentu, stoi w sprzeczności $z$ zasadą pewności prawa, zapewniającą jednostce bezpieczeństwo prawne i umożliwiającą jej decydowanie o swoim postępowaniu w oparciu o pełną znajomość przesłanek działania organów państwowych oraz konsekwencji prawnych, jakie jej działania mogą pociągnąć za sobą. Stanowi bowiem ograniczenie ich praw w stosunku do praw osób fizycznych i prawnych z Anglii, Niemiec czy Francji, mających dostęp do obowiązujących w systemie wzmocnionej współpracy patentów w ich językach macierzystych.

Jednakże zgodnie $z$ art. 4 ust. 1 rozporządzenia Rady UE nr 1260/ /2012 z dnia 17 grudnia 2012 r. wprowadzającego wzmocnioną współpracę w dziedzinie tworzenia jednolitego systemu ochrony patentowej w odniesieniu do mających zastosowanie ustaleń doty-

27 Zob. wyrok Trybunału Sprawiedliwości Unii Europejskiej (Wielka Izba) z dnia 27 listopada 2012 r. w sprawie C-566/10 P Republika Włoska przeciwko Komisji Europejskiej, http://www.curia.europa.eu (dostęp: 31 sierpnia 2014 r.). 
czących tłumaczeń, w przypadku sporu dotyczącego domniemanego naruszenia patentu europejskiego o jednolitym skutku, uprawniony do patentu przedstawia, na żądanie i zgodnie $z$ wyborem domniemanego sprawcy naruszenia, pełne tłumaczenie patentu europejskiego o jednolitym skutku na język urzędowy uczestniczącego państwa członkowskiego, w którym miało miejsce domniemane naruszenie, albo państwa członkowskiego, w którym ma siedzibę domniemany sprawca naruszenia ${ }^{28}$.

Należy jednak zwrócić uwagę, że umożliwienie zapoznania się domniemanych naruszycieli $\mathrm{z}$ danym patentem dopiero $\mathrm{w}$ chwili wyniknięcia sporu jest działaniem zdecydowanie spóźnionym, gdyż powstanie sporu generuje już niemałe koszty po stronie danego przedsiębiorcy. Dostępność baz patentowych w językach narodowych umożliwiłaby uniknięcie wdawania się w niepotrzebny spór. Wprawdzie powództwa o naruszenie mogą być wnoszone również do oddziałów lokalnych i regionalnych państwa naruszenia, jednakże nie w każdym państwie taki oddział będzie utworzony.

Mimo że skargi Królestwa Hiszpanii i Republiki Włoch zostały oddalone przez Trybunał Sprawiedliwości Unii Europejskiej, to jednak warto się nad ich zasadnością jeszcze raz zastanowić. Jednym $z$ argumentów Trybunału był fakt, że nie ma zakazu organizowania się państw członkowskich we wzmocnioną współpracę. Jednakże kognicja JSP rozciągać się ma również na państwa, które do niej nie przystąpiły. Należy zwrócić uwagę, że nawet gdy uprawniony do patentu wybierze ochronę patentu europejskiego, wymagającego walidacji, to w przypadku wyniknięcia sporu, jurysdykcję i tak będzie sprawował JSP. Argument zatem, iż wzmocniona współpraca dotyczy tylko państw, które do niej przystąpiły, nie oddaje stanu rzeczywistego. W rzeczywistości państwa, które nie ratyfikowały umowy o JSP, i tak będą objęte jego kognicją i to w języku obcym dla ich obywateli. Kłóci się to $z$ brzmieniem art. 327 TFUE, zgodnie z którym wzmocniona współpraca nie narusza kompetencji, praw i obowiązków państw członkowskich, które w niej nie uczestniczą.

${ }^{28}$ Kwestia ta jest również uregulowana w art. 31 umowy o Jednolitym Sądzie Patentowym (2013/C 175/01). 


\subsection{Koszty}

Jedną z głównych przyczyn wprowadzania systemu jednolitej ochrony patentowej w Unii Europejskiej są dotychczas generowane koszty. Obecnie uzyskanie ochrony porównywalnie szerokiej do jednolitego patentu kosztuje ok. 40 tysięcy euro. Aż 70\% tej kwoty to wydatki na tłumaczenia dokumentów na wszystkie unijne języki. Po wprowadzeniu jednolitej ochrony patentowej koszty te mają być zredukowane do ok. 6,2 tysięcy euro, z czego tylko 10\% obejmowałoby tłumaczenia na angielski, niemiecki i francuski ${ }^{29}$. Wynika to $z$ braku obowiązku dalszych tłumaczeń na języki urzędowe państw, w których ma być wprowadzona ochrona patentowa, a który to obowiązek istnieje przy zwykłym patencie europejskim.

Różnica w szacowanych kosztach jest znacząca. Jednakże nie można nie wspomnieć o prawdopodobnym wzroście wydatków ponoszonych bezpośrednio przez przedsiębiorców. Przykładowo system językowy jednolitych patentów może znacząco pogorszyć pozycję podmiotów polskich, które przy podejmowaniu lub prowadzeniu działalności gospodarczej będą musiały dokonywać tłumaczeń tych patentów na własny koszt i na własne ryzyko ${ }^{30}$. „To my poniesiemy koszty związane $z$ tłumaczeniami tych dokumentów. Do tego olbrzymie ryzyko prawne związane $z$ tym, czy naruszamy już, czy jeszcze nie jakieś patenty, które zostały już przyznane" ${ }^{31}$. W efekcie na jednolitym systemie ochrony patentowej ucierpieć ma

${ }^{29}$ Zob. Mamy patent na oszczędności dla firm, http://mg.gov.pl /node/15625 (dostęp: 31 sierpnia 2014 r.).

30 Zob. P. Rosół, Ł. Wściubiak, A. Stachowski, W. Rożnowski, Uwagi do ekspertyzy „Korzyści, szanse i zagrożenia wynikajace z jednolitego systemu ochrony patentowej dla jednostek naukowych" sporzadzonej przez Pania dr hab. prof. UW K. Szczepanowską-Kozłowska na zamówienie Ministerstwa Nauki i Szkolnictwa Wyższego z 29 września 2012 r., http: / www.rzecznikpatentowy. org.pl/nie_dla_pat_jed/2012-10-19_POLEMIKA_Uwagi_do_opinii_Prof_Szczepanowskiej-1k_pr_wr_as-final_120929.pdf, s. 3 (dostęp: 31 sierpnia 2014 r.).

31 Wypowiedź K. Urbańskiej - radcy prawnego, dyrektora Departamentu Prawnego PKPP Lewiatan, http://wgospodarce.pl/informacje/2331-jednolitypatent-europejski-eksperci-sa-przeciw (dostęp: 27 marca 2015 r.). 
polska gospodarka. Oszacowany wynik netto, polegający na odjęciu kosztów od korzyści, wykazuje, że przy niewiązaniu się jednolitą ochroną patentową Polska zaoszczędziłaby 52300000 miliardów zł w okresie 20 lat, a w okresie lat $30-78100000$ miliardów zł ${ }^{32}$.

Istotny jest fakt, że zwolnienie zgłaszających patent $\mathrm{z}$ obowiązku tłumaczeń opisów patentowych oznacza przerzucenie kosztów tłumaczeń na podmioty działające w państwach, których językiem urzędowym jest język inny niż angielski, francuski czy niemiecki ${ }^{33}$. Koszty walki $z$ atakiem o nawet rzekome naruszenie kształtują się na poziomie średnio 230 tysięcy euro. Zwiększone koszty takich gospodarek jak nasza polegać będą również na tym, że polscy przedsiębiorcy będą zmuszeni badać tzw. czystość patentową w trzech uprzywilejowanych językach obcych oraz korzystać w głównej mierze $z$ usług rzeczników patentowych, tłumaczy i prawników zagranicznych. Efektem zwielokrotnionej liczby patentów będą też znacząco wyższe wydatki na nabywanie licencji. Dla podmiotów polskich jurysdykcja JSP może oznaczać ograniczenie dostępu do sądu, poważny wzrost kosztów postępowań, utrudnienie obrony przed zarzutami, często bezzasadnymi, naruszenia cudzych praw ${ }^{34}$. Przedsiębiorcy z Rzeczypospolitej Polskiej mogą stanąć w obliczu sytuacji, w której większość ważnych patentów publikowana jest w obcym języku, a liczba patentów jest wielokrotnie większa niż obecnie. Sprawy o naruszenia patentów toczone będą przed obcym sądem, poza granicami Polski, a obce prawo, do którego przedsiębiorcy będą musieli się stosować, może być dużo bardziej restrykcyjne $^{35}$. Mimo że system jednolitej ochrony patentowej może zostać

${ }^{32}$ Zob. Analiza Deloitte na zlecenie Ministerstwa Gospodarki z dnia 1 października 2012 r. w sprawie potencjalnych skutków gospodarczych wprowadzenia w Polsce systemu jednolitej ochrony patentowej, http://www.isoc.org. pl/system/files/deloitte.pdf, s. 6 (dostęp: 31 sierpnia 2014 r.).

${ }^{33}$ A. Nowicka, Jednolita ochrona patentowa i Jednolity Sad Patentowy uwagi krytyczne, Poznań 2012, s. 6.

${ }^{34}$ A. Nowicka, R. Skubisz, Pakiet patentowy (ocena z perspektywy Polski), „Europejski Przegląd Sądowy” kwiecień 2013, s. 19.

35 Możliwość stosowanie prawa obcego dla przedsiębiorców prowadzących działalność gospodarczą na terenie Polski wynika z postanowień projektu Porozumienia w sprawie Jednolitego Sądu Patentowego - art. 24 ust. 1 lit. e. 
wprowadzony dopiero po ratyfikacji przez 13 państw, to „Już teraz firmy globalne zwracają się do firm z branży oświetleniowej z pismami ostrzegającymi i wzywającymi do zaniechania produkcji lub proponują podpisanie bardzo niekorzystnej umowy licencyjnej. Powołują się przy tym na patenty, które nie obowiązują w Polsce. W firmach pojawia się przedstawiciel firmy globalnej, który jednoznacznie stwierdza, że jeżeli zarząd firmy nie podpisze umowy licencyjnej, to będzie musiał to uczynić zaraz po przystąpieniu Polski do współpracy w ramach patentu europejskiego o jednolitym skutku. W przeciwnym wypadku firmy czekają bardzo kosztowne procesy"36.

\subsection{Dyskryminacja \\ małych i średnich przedsiębiorców}

Zgodnie $\mathrm{z}$ rozporządzeniem Rady, ustalenia dotyczące systemu tłumaczeń powinny zapewniać pewność prawną i stymulować innowacje oraz w szczególności przynosić korzyści mśp. Powinny ułatwić dostęp do patentu europejskiego o jednolitym skutku oraz do systemu patentowego jako całości, a także obniżyć koszty tego dostępu i zapewnić bezpieczeństwo pod względem prawnym ${ }^{37}$.

Brzmienie przytoczonego rozporządzenia wskazuje na wewnętrzną sprzeczność systemu tłumaczeń. Celem jednolitej ochrony patentowej jest m.in. ułatwienie dostępu do ochrony patentowej, zmniejszenie kosztów, usprawnienie systemu. O ile w stosunku do wnioskodawców system ten spełni swoją funkcję, to w odniesieniu do przedsiębiorców, w tym mśp - potencjalnych naruszycieli patentu, w znacznym stopniu utrudni prosperowanie na rynku, biorąc pod uwagę omówioną niepewność prawną oraz faktyczną, m.in.

${ }^{36}$ Wypowiedź M. Orłowskiego prezesa Polskiego Związku Przemysłu Oświetleniowego, eksperta Zachodniej Izby Gospodarczej, http://www.for.org.pl/pl/ debaty (dostęp: 31 sierpnia 2014 r.).

37 Rozporządzenie Rady Unii Europejskiej NR 1260/2012 z dnia 17 grudnia 2012 r. wprowadzające wzmocnioną współpracę w dziedzinie tworzenia jednolitego systemu ochrony patentowej w odniesieniu do mających zastosowanie ustaleń dotyczących tłumaczeń (D.Urz. UE L 361/89). 
właśnie w związku z ograniczonym zakresem tłumaczeń w systemie jednolitego patentu europejskiego.

Jednak należy zauważyć, że system jednolitej ochrony zapewnia również możliwość skutecznego wnioskowania o zwrot kosztów tłumaczeń dla mśp ${ }^{38}$. Jest to szczególnie istotne dla polskich przedsiębiorców, gdyż z działających w naszym kraju ok. 1,78 milionów przedsiębiorców aż 99,8\% stanowią mśp ${ }^{39}$. Artykuł 4 ust. 4 Rozporządzenia Rady (UE) NR 1260/2012 stanowi, iż przy naruszeniu patentu przez mśp należy brać pod uwagę, że sprawca mógł działać, nie wiedząc o dokonanym naruszeniu. Jest to istotne głównie z powodu braku tłumaczeń oraz mniejszych środków finansowych na zatrudnienie rzeczników patentowych czy tłumaczy. Należy jednak brać pod uwagę, że w przytaczanym rozporządzeniu nie skonkretyzowano, na zwrot w jakiej wysokości przedsiębiorcy mogą liczyć.

Republika Federalna Niemiec jest krajem, w którym spory patentowe występują znacznie częściej niż w pozostałych państwach europejskich $^{40}$. Koszty, $z$ jakimi musi się liczyć pozwany, są nawet sześciocyfrowe. Polscy przedsiębiorcy powinni poważnie brać pod uwagę ryzyko wchodzenia na rynek niemiecki, gdyż spotkanie się $\mathrm{z}$ atakiem miejscowych firm jest bardzo prawdopodobne. Jednak fakt, że mamy Urząd Patentowy RP, przed którym można unieważnić patent, powoduje, iż nie tak chętnie wychodzą $z$ roszczeniami na terenie Polski. Sytuacja może diametralnie zmienić się $\mathrm{w}$ razie obowiązywania w Polsce patentu europejskiego o jednolitym skutki oraz JSP.

38 Rozporządzenie Rady UE z dnia 10 marca 2011 r. w sprawie upoważnienia do podjęcia wzmocnionej współpracy w dziedzinie tworzenia jednolitego systemu ochrony patentowej (2011/167/UE).

${ }^{39}$ Raport o stanie sektora małych i średnich przedsiębiorstw w Polsce w latach 2011-2012, Polska Agencja Rozwoju Przedsiębiorczości, http://www. parp.gov.pl /index/more/37123 (dostęp: 31 sierpnia 2014 r.).

${ }^{40}$ Por. Patent Litigation Insurance, A study for the European Commission on the feasibility of possible insurance schemes against patent litigation risks, Appendices to the Final Report, June 2006, http:/ /ec.europa.eu/internal_market/indprop/docs/patent/studies/pli_appendices_en.pdf (dostęp: 21 marca 2015 r.). 
Nie oznacza to, że jednolita ochrona patentowa jest pomysłem zupełnie nietrafionym. Dla przedsiębiorców, którym zależy na uzyskaniu szerokiej ochrony własności patentu, będzie korzystna. Szczególnie, że koszty związane $z$ systemem tłumaczeń patentu europejskiego oscylują wokół 40\% wszystkich kosztów uzyskania patentu, dlatego jednolity patent europejski pozwoli na ich redukcję, przynajmniej jeżeli chodzi o zgłaszających patent ${ }^{41}$. Należy przypomnieć również, że jednolity patent europejski automatycznie daje ochronę we wszystkich państwach objętych wzmocnioną współpracą. Jeżeli uprawniony z patentu chciałby uzyskać tak szeroką ochronę przy pomocy patentu europejskiego, koszty związane $z$ samym uzyskaniem ochrony byłyby około ośmiokrotnie wyższe ${ }^{42}$.

Jednakże podnosi się, że system jednolitej ochrony patentowej przyniesie korzyści jedynie państwom rozwiniętym technologicznie, a pozycja przedsiębiorstw polskich ulegnie pogorszeniu ${ }^{43}$.

\section{Podsumowanie}

System tłumaczeń jednolitej ochrony patentowej może być odbierany dwojako, w zależności od tego, czy zainteresowany jest uprawnionym do patentu, czy też potencjalnym naruszycielem. $Z$ pewnością zredukuje wydatki zgłaszających patent, na czym w dużej mierze skorzystają państwa przodujące pod względem liczby przyznawanych patentów. Jednak pogorszy to sytuację podmiotów słabszych pod względem innowacyjności, dopiero wkraczających na rynek.

${ }^{41}$ Commission Staff Working Paper - Impact Assessment, Accompanying document to the proposal for a Regulation of the European Parliament and the Council implementing enhanced cooperation in the area of the creation of unitary patent protection and proposal for a Council Regulation implementing enhanced cooperation in the area of the creation of unitary patent protection with regard to the applicable translation arrangements, Komisja Europejska, Bruksela, 15 kwietnia 2011 r., s. 14.

42 http://www.mg.gov.pl/Wspieranie+przedsiebiorczosci/Jednolity+patent +europejski (dostęp: 31 sierpnia 2014 r.).

${ }^{43}$ A. Nowicka, R. Skubisz, Pakiet patentowy (ocena z perspektywy Polski), „Europejski Przegląd Sądowy” kwiecień 2013. 
Brak obowiązku tłumaczenia na język państw, w których patent ma obowiązywać, stawia w zdecydowanie gorszym położeniu przedsiębiorców prowadzących na ich terytorium działalność gospodarczą ${ }^{44}$. Taka zmiana wprowadza niebezpieczny element braku pewności co do sytuacji patentowej we własnym państwie ${ }^{45}$. Zwłaszcza mśp mogą odczuć dotkliwie skutki wprowadzenia systemu jednolitej ochrony. Wprawdzie rozporządzenie zawiera regulacje uwzględniające pozycję mśp oraz innych podmiotów, które mogły nieświadomie naruszyć czyjąś własność patentową ${ }^{46}$, jednakże takie rozwiązanie nie wydaje się odpowiednie, gdyż otwiera pole do nadużyć.

Analiza przeprowadzona przez firmę Deloitte wykazała jednak, iż po dokonaniu rzeczywistego rozrachunku zysków i strat, bardziej korzystne dla gospodarki polskiej byłoby nieprzystąpienie do wzmocnionej współpracy oraz niepodpisanie porozumienia o jednolitym sądzie patentowym. W ustaleniach uwzględniono okoliczność, że polscy przedsiębiorcy będą mogli korzystać z jednolitego patentu europejskiego także w sytuacji, gdy Polska nie ratyfikuje umowy o jednolitym sądzie patentowym ${ }^{47}$.

Nie można nie zwrócić uwagi na uprzywilejowanie Anglii, Niemiec i Francji w systemie jednolitej ochrony patentowej. Przedsiębiorcy z tych państw, którzy już teraz są dużo bardziej rozwinięci pod względem gospodarczym, mają znacznie ułatwioną sytuację patentową. Udostępnianie baz patentowych wyłącznie w językach obcych przedsiębiorcom $\mathrm{z}$ pozostałych państw członkowskich jest pogwałceniem celów Unii Europejskiej, dla których realizacji wzmoc-

${ }^{44}$ Zob. K. Szczepanowska-Kozłowska, Korzyści, szanse i zagrożenia wynikajace z jednolitego systemu ochrony patentowej dla jednostek naukowych, Warszawa 2012, s. 51.

${ }^{45}$ Zob. A. Nowicka, Finalizacja procesu tworzenia jednolitej ochrony patentowej i jednolitego sądu patentowego (stan na 26 listopada 2012 r.), Poznań 2012 , s. 8.

${ }^{46}$ Zob. Rozporządzenie Rady UE z dnia 10 marca 2011 r. w sprawie upoważnienia do podjęcia wzmocnionej współpracy w dziedzinie tworzenia jednolitego systemu ochrony patentowej (2011/167/UE).

${ }^{47}$ Zob. Analiza Deloitte na zlecenie Ministerstwa Gospodarki. 
niona współpraca miała być utworzona ${ }^{48}$, a do których należy zwalczanie dyskryminacji. Ciężko jednak wyobrazić sobie rozwiązanie, w którym języki wszystkich państw członkowskich byłyby językami urzędowymi $\mathrm{EPO}^{49}$.

\title{
STRESZCZENIE
}

Dyskryminacja pod względem językowym w systemie jednolitej ochrony patentowej

W niniejszym artykule autorka odnosi się do systemu jednolitej ochrony patentowej, którego wprowadzanie wywołuje od ponad dwóch lat liczne dyskusje. Celem opracowania naukowego jest omówienie problemu dyskryminacji w Unii Europejskiej. Autorka skupia się na kwestii uprzywilejowania pod względem językowym niektórych państw członkowskich i wskazuje konsekwencje, $z$ jakimi należy liczyć się po wprowadzeniu systemu w obecnym kształcie. Przytaczane są opinie autorytetów w dziedzinie prawa patentowego, a także podmiotów gospodarczych, na których działalność planowana zmiana może najbardziej wpłynąć.

Słowa kluczowe: jednolity patent europejski; dyskryminacja; język

\section{SUMMARY}

\author{
Language discrimination \\ in the European Unitary Patent system
}

The author of the article elaborates on a European patent with unitary effect which has been a subject of many discussions for at least last two years. The aim of the article is to discuss the problem of discrimination within the European Union that unitary patent regulations may cause. The author focuses on the favoring some Member States in terms of language regime and indicates the consequences that should be taken into account after introducing the new system. The conclusions the author makes are

${ }^{48}$ Zob. art. 367 Traktatu o Unii Europejskiej, wersja skonsolidowana: Dz.Urz. UE C 83 z dnia 30 marca 2010 r.

49 Zob. K. Szczepanowska-Kozłowska, op.cit., s. 53. 
based on the collected materials, including regulations and the opinions of authorities.

Keywords: unitary patent effect; discrimination; language

\section{BIBLIOGRAFIA}

Kopaliński W., Słownik wyrazów obcych i zwrotów obcojęzycznych, Warszawa 1988.

Nowicka A., Finalizacja procesu tworzenia jednolitej ochrony patentowej i jednolitego sądu patentowego (stan na 26 listopada 2012 r.), Poznań 2012.

Nowicka A., Jednolita ochrona patentowa i Jednolity Sąd Patentowy - uwagi krytyczne, Poznań 2012.

Nowicka A., Kontrowersje dotyczące utworzenia jednolitej ochrony patentowej oraz Jednolitego Sądu Patentowego. Analiza prawna (stan na 27 stycznia 2012 r.), Poznań 2012.

Nowicka A., Skubisz R., Pakiet patentowy (ocena z perspektywy Polski), „Europejski Przegląd Sądowy” kwiecień 2013.

Siuta J., Słownik psychologii, Kraków 2005.

Szajkowski A., Patent tymczasowy. Patent. Świadectwo autorskie, w: Komentarz do prawa wynalazczego, red. S. Sołtysiński, A. Szajkowski, T. Szymanek, Warszawa 1990.

Szczepanowska-Kozłowska K., Korzyści, szanse i zagrożenia wynikające $z$ jednolitego systemu ochrony patentowej dla jednostek naukowych, Warszawa 2012.

Ullrich H., Harmonizing patent law: the untamable union patent, Max Planck Institute for Intellectual Property and Competition Law Research Paper No. 12-03.

Ullrich H., Patent Protection in Europe: Integrating Europe into the Community or the Community into Europe?, European University Institute, Florence department of law, EUI Working Paper LAW No. 2002/5.

Vall M. du, Prawo patentowe, Warszawa 2008. 
